\title{
A Macabre Decay of the Human Body: A Study of Select Black Death Paintings
}

\author{
Jane Mary Joseph \& K.C. Lalthlamuani
}

\begin{abstract}
The horror of the human experience during the Black Death was captured by artists in their paintings. As opposed to the art that existed for centuries before the plague, the Black Death paintings presented grotesque images of the human body which became the primary site of suffering. From the dark motifs of people helplessly witnessing their bodies decay to skeletons ruling over the living, artists offered a macabre eye to view the lived experiences of the pandemic through art. The grotesque is evident not only in the effects of the plague on the physical body but also on the human mind. Many abandoned their families who were infected by the disease for fear of contracting it. The apocalyptic approach adopted in these works posits a marked departure in the perception of religion from the times before the plague hit Europe. The pandemic, which appeared to be the devil's slaughter, led to a general disillusionment with religion. The beliefs that Christianity formed the centre of human existence and that it triumphed over death were overturned with the advent of the plague. The artists brought to life these grim sights around them. The gradual decaying of the bodies of one's neighbors, the streets filled with corpses, and the victory death had over life occupied the canvases, thus providing evidence for posterity on how the pandemic caused decay of the human body, and through it, the breaking down of established orders and belief systems.
\end{abstract}

Keywords: Death, Grotesque, Human Body, Otherness, Religion.

\section{Introduction}

The Middle Ages were a time when Europe witnessed unparalleled changes in terms of economic growth. While trade contributed to Europe's relationship with other nations, it also brought with it the deadly bubonic plague. "The Black Death of 1348-49 was the greatest biomedical disaster in European and possible world history ... [one] third at least of Western Europe's population died in what contemporaries called 'the pestilence"' (Cantor, 2001, p. 7). The effects that the plague had on Europe would remain etched in its memory and echoed in the works of art and literature of the period.

The physical anguish caused by the plague was such that it left an indelible mark on the minds of not only the victims, but also on those of its witnesses.

In men and women alike it first betrayed itself by the emergence of certain tumors in the groin or armpits, some of which grew as large as a common apple, others as an egg ... From the two said parts of the body this deadly gavocciolo soon began to 
propagate and spread itself in all directions indifferently; after which the form of the malady began to change, black spots or livid making their appearance in many cases on the arm or the thigh or elsewhere, now few and large, now minute and numerous. And as the gavocciolo had been and still was an infallible token of approaching death, such also were these spots on whomsoever they showed themselves. (Boccaccio, 1353).

The Black Death not only affected the physical body of man, but also had deep psychological implications. While the victims suffered from both physical pain and psychological agony, the observers who lost family and friends to the pandemic had to deal with an inexplicable trauma that would remain. The plague also brought the human mind to a state where it died a slow death when man was forced to place his own self before even those closest to him. "Father abandoned child, wife husband, one brother another" (Tuchman, 1978, p. 96) when it came to survival. Further, it deeply impacted the psyche of man to the extent that he set out in the quest of a scapegoat, which explains the hysterical action of killing the Jews.

\section{Triumph of Death (c. 1350) by Francesco Traini}

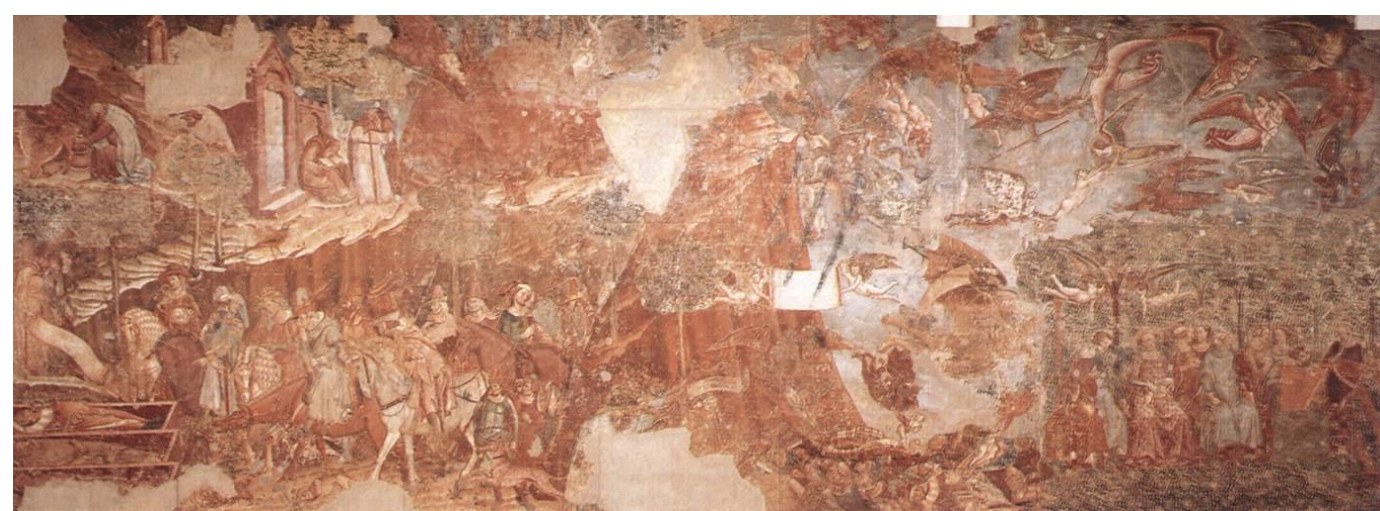

Figure 1: Triumph of Death, Note. Source: Web Gallery of Art, n.d.

The first painting, Triumph of Death (c. 1350) in the Camposanto Monumental, Pisa by an Italian painter Francesco Traini is a narrative painting comprising seven scenes, all of which depict the Black Death. It suffered damage during the Second World War and was removed from the Camposanto Monumental in 1948 after which it was "restored and returned to its original place" (Carrade, 2016, p. 7). The painting is also a personal document as Traini himself witnessed several of his family members and townspeople succumb to the horrific disease. The overarching theme of death in the painting can be attributed to his trauma on seeing scores of dead bodies around him and is perhaps, his response to the harrowing experience.

The Triumph of Death brings forth a clear distinction between the spiritual world which forms the upper part of the fresco and the physical world which forms the lower part. Though there appears to be no narrative connection between the scenes, the inevitability of death that grips the beholder is the overarching theme in each of them.

For all its imbedded narrative, it does not claim unity of action or unity of space but offers a conceptual arrangement that organizes the many narrative units. The single episode is as real as the overall structure is abstract. The subject can be described as the power of death to dash all earthly hope. (Boeckl, 1997, p. 58). 


\subsection{The Three Dead and the Three Living}

The first scene of the painting derives from a French legend where three young noblemen who are out hunting discover three corpses in their coffins in different stages of decomposition. The first body wears an elegant hat and footwear, the second has a crown on his head while his body is bloated, and the third is a skeleton that faces the beholder, serving as a memento mori or a reminder of death. Traini, here, breaks the thin line separating the dead from the living. The bodies of the dead are the inevitable end state of the living and "the grotesque body is not separated from the rest of the world. It is not a closed, complete unit; it is unfinished, outgrows itself, transgresses its own limits" (Bakhtin, 1965, p. 26). The olfactory images add to the grotesquerie when the smell and sight in front of them greatly disgust the three noblemen. The presence of corpses accounts for the rising interest that most artists had during this period with the subjects of death and decay. The painting serves as a reminder for the living, "what we were you are; what we are, you will be" (Carrade, 2016, p. $11)$.

\subsection{Waiting for Death}

The second scene shows beggars in the physical world who are "a wretched group of lepers, cripples, and beggars ... one with his nose eaten away, others legless or blind or holding out a cloth-covered stump instead of a hand, implore Death for deliverance" (Tuchman, 1978, p. 124). The deformed appearances of the beggars add to the dark nature of the painting. Their physical bodies have given up on them and the only solace they have is the hope of Death, a stark contrast to earlier periods when works of art explored the joys of life. This scene can also be interpreted as the response of "the semi-hysterical state of mind of millions in Europe" (Thompson, 1921, p. 570). The psychological impact of the harrowing experience of decay and death holds true for not just the victims of the plague, but also for the general public whose mental agony on beholding the grim scenes around would have led them to plead for death.

\subsection{Death is a Leveler}

The macabre decay of the human body is further stressed in the third scene which is filled with corpses, again a fitting picture of the physical world. "In a heap of corpses nearby lie crowned rulers, a Pope in tiara, a knight, crumbled together with the bodies of the poor" (Tuchman, 1978, p. 124). Traini here draws on the ultimate truth that Death is a leveler who does not discriminate on any grounds. While Traini's painting depicts how all men are equal in death, it could also be seen as a precursor to the much-needed change in socio-economic systems in Europe. The Black Death ended feudalism in Europe, an event that can be considered in post-colonial terms as the assertion of rights and entitlements of the indigenous people. The peasants earlier were subjected to a system which disguised "the power relations that shape a seemingly shapeless world and contributes to a conceptualization of that world that both consolidates and subverts possibilities of resistance" (Dirlik, 2005, p. 584).

\subsection{Personification of Death}

Traini's personification of Death in the fresco is seen in the fourth scene. He neither uses the early to mid fourteenth century symbol of a corpse holding a weapon of death nor the image of the Grim Reaper in a black cloak with a scythe in hand. The representation of Death here is as a "black-cloaked old woman with streaming hair and wild eyes, carrying a broad-bladed 
murderous scythe" (Tuchman, 1978, p. 123). The grotesque nature of Traini's symbol of Death lies in its duality of being both human and beast - an old woman with dark wings on her back, with clawed feet holding the scythe. Such a representation not only evokes fear in the beholder but leads him to realize the duality of his own personality. The Black Death shed light on the hybridity of all species, of how man and animal are considered to be binary opposites but are essentially the same.

The hybrid combination of human and animal lies at the heart of the figurative vocabulary through which Jane Alexander's sculptural tableaux summon us into the imaginative domain of the "humanimal"- a domain where the boundaries by which religion, philosophy and science have separated men, gods and beasts are torn apart, and where the rules and conventions that ordinarily seek to impose order over our world take a tumble. (Mercer, 2013, p. 80).

\subsection{A Transient Life}

The fifth scene shows a group of seven young ladies and three noblemen who are carefree. They are blissfully unaware of the impending darkness in the form of Death hovering over them. Even when faced with death, men failed to perceive the meaning of a life beyond "superficial yet fevered gaiety, the proneness to debauchery, the wild wave of extravagance, the flamboyant luxury, the gluttony in restaurant and café (Thompson, 1921, p. 570). Traini uses this scene to comment on how more often than not, the human mind is so preoccupied with worldly pleasures that he fails to see the meaninglessness attached to them and how transient life itself is.

\subsection{The Battle for the Souls}

In the sixth scene, Traini presents the beholder with a battle between the angels and the devils for the souls of those who died from the plague. The macabre death of the human soul, together with the body is seen when the devils take some souls (represented as small, naked figures) from the mouth of the dead and carry them to the burning mountain to be thrown into hell, while others are saved by the angels. One should note that during the Black Death, Europeans reasoned that the plague was either the result of scandalous attire which caused God to punish them by unleashing the plague or that the Jews attempted to murder the Christians. The latter belief caused a large populace of the Jewish community was exterminated. While Traini does not directly hint at the killing of the Jews in his painting, he perhaps makes an oblique reference to it through the image of the soul leaving body in this scene. He would have the knowledge that "in Judaism there is a belief that when a human dies, his soul leaves the body through the mouth" (Carrade, 2016, p. 16). This hints at the idea that both the Christians and the Jews were victims of the plague and that it was not intentionally brought up on Europe by any one group.

\subsection{Acceptance of Death}

The last scene in the painting portrays a peaceful existence of men in the spiritual world that is far removed from the chaotic life of the physical world. What should be noted here is that while they perform their daily chores, the anchorites and hermits wait for Death. It differs from the previous scenes, in that it views Death in the light of acceptance and not of fear. This reverberates with the minds of many Europeans who lived through the plague and struggled with "an exceptionally strong sense of guilt and a truly dreadful fear of retribution, 
seeking expression in a passionate longing for effective intercession and in a craving for direct, personal experience of the Deity" (Langer, 2011, p. 2).

\section{Dance of Death (c. 1463-1466) by Bernt Notke}

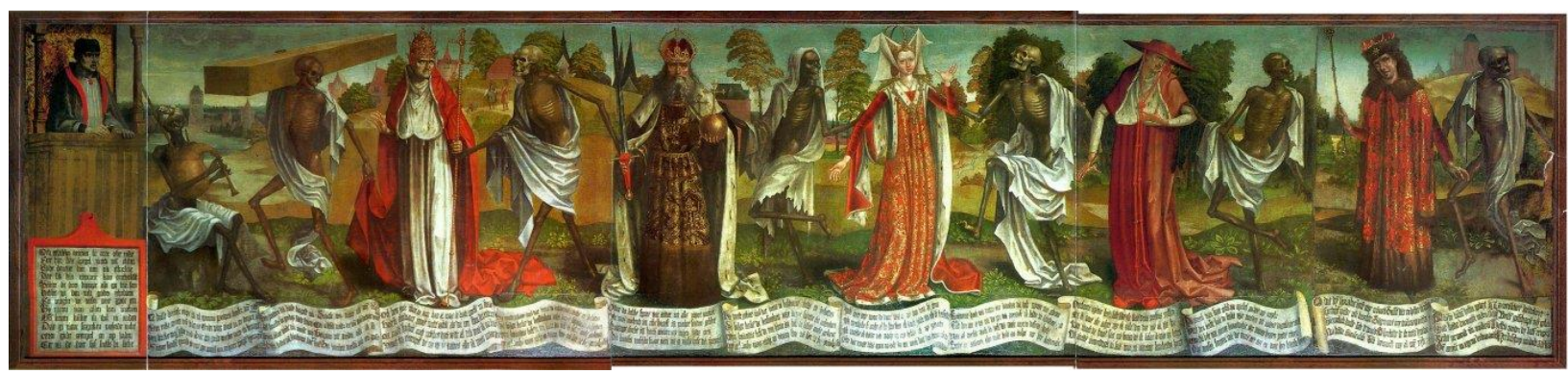

Figure 2: Dance of Death, Note. Source: Wordpress, 2011.

The second painting, Dance of Death (c. 1463-1466) by Bernt Notke is housed in St. Anthony's Chapel of St. Nicholas' Church, Estonia. It is one of the most famous works of the late medieval Dance of Death paintings. The painting suffered damages and currently has only two fragments remaining which provide "a limited visual of only seven and a half meters of the original painting that is believed to have been thirty meters long" (Carrade, 2016, p. 23). It shows a Preacher who stands in a pulpit and warns man about the inevitability of Death. Next to him is seated a skeleton dressed in linen and playing his bagpipes, who appears to stare at the beholder. It is believed that these bagpipes were used to awaken the dead. To the right of this figure is yet another skeleton draped in linen. On his right shoulder, he carries a coffin while with the left hand he pulls the Pope into the Danse Macabre. The frowning Pope with his papal tiara and crosier is led by the skeleton to the dance where eerie visuals of skeletons dancing in grotesque manners form part of the fresco.

A grinning skeleton follows, and after him comes the Holy Roman Emperor, with orb and sword. Death, covered in a torn shroud grabs his shoulder as well as the elbow of the Empress, who raises her left arm towards the sky in an exaggerated gesture of sorrow. Then follows another skeleton, who leads a Cardinal dressed in red, his hand reaching to his heart. The panel continues with Death, who turns toward the King with scepter, followed in turn by the remaining skeleton. (Gertsman, 2003, p. 145).

The procession is headed towards their graves and is complete with a Duke, an Abbot, a Knight, a Craftsman, a Hermit, a Peasant, a Youth, a Maiden, and a Child in a cradle.

Notke's painting depicts how death is always tied to life. While it revolves around the universality of death, it also dwells on how no matter what one's station in life is, Death would one day come to take everyone. Artists who lived during the pandemic were greatly influenced by this thought. Such works produced under the impact of the Black Death remind one of how fleeting life is and how meaningless the glories of earthly life are.

The plague brought to light the divide in fourteenth century European society. The concept of otherness which forms an essential part of post-colonialism divides the world into opposites - the 'self' and the 'other'. The latter is a construct which is demonizing in nature and is, at its core, an expression of "ambivalence at the heart of authority" (Ashcroft et al., 2002 , p. 3). While power structures may appear remodeled and shifted in the post-colonial world, these systems existed even during the devastating bubonic plague. While some Christians believed that it was God's wrath that came in the form of the plague, others deemed it fit to blame the Jews. A large number of Jews were burnt alive during the Black 
Death as it was believed that they poisoned the wells of Christians causing them to fall ill. Though there were no concrete grounds on which the Jews could be blamed, they were made the scapegoats of the plague owing to years of hatred and prejudice. The persecution of Jews was not new in Europe, but this would remain the largest massacre in its history. What artists like Notke stress on is that regardless of the futile barriers man creates, death would embrace every man the same.

\section{A Fifteenth Century Chronicle of Constance}

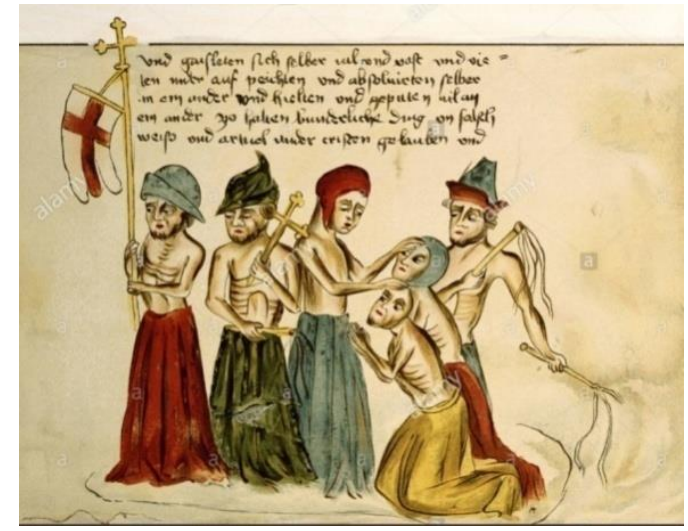

Figure 3: A Fifteenth Century Chronicle of Constanc, Note. Source: Pinterest, n.d.

The third painting is from a fifteenth century chronicle of Constance. The plague-stricken Europe also witnessed a group of people who believed that they ought to inflict pain not only on other races but on themselves as well. This set of people who came to be known as the flagellants displayed hysteria and beat themselves to imitate Christ's suffering. They were lead by the belief that by doing so, they would gain God's forgiveness and be protected from the plague. They wore white robes, hoods, and capes which were decorated with crosses and were "pulled down around their waists before ritualistically beating themselves with a threethong whip tipped with sharp metal" (DesOrmeaux, 2007, p. 57). The flagellants gave themselves to the cult for a period of thirty-three days during which they observed an abstinence from sex, bathing and shaving.

They marched down the street in procession ... [then] enter the church ... cover their bodies from the navel down, leaving the upper part totally nude. They take up the whips in their hands. [T] he senior flagellant ... prostrates himself upon the ground ... after him the second ... then the third ... and so on in succession. After this, one of them strikes the first flagellant with a whip, saying: "God grants you remission of all your sins, arise!" And he gets up. Then he does the same to the second and so on through the order. [They] start to sing in a high voice a religious song. [W] henever in the course of their psalmody they come to a part of the song where the passion of Christ is mentioned, all together they suddenly throw themselves to the ground ... wherever they happen to be and on whatever is lying there, either on the earth, or on mud, or thorns, or thistles, or nettles or stones. They do not fall down in stages on their knees ... but they drop like logs, flat upon their belly and face with their arms outstretched. (Aberth, 2005, p. 123-24).

While some people did not find these actions sensible, the greater part of commoners praised the flagellants and approved what they did. "You should know that whenever the flagellants whipped themselves there were large crowds and the greatest pious weeping that one should ever see" (Aberth, 2005, p. 130). People welcomed the flagellants to their houses and 
bestowed them with gifts and money as they were said to possess miraculous powers. The manner in which they were accepted by the general public shows how grotesque man's psyche can be, one that can be twisted to convenience, by transforming a religion whose peaceful ideologies they believed in to that which advocated bloodshed. It also shows how profound an impact the plague had on the minds of people to drive them to resort to such extreme measures to save themselves.

\section{Conclusion}

The paintings discussed here are direct symbols of the catastrophe of the plague and the sufferings of those who were its victims. The manner in which the plague affected the human body and man's psyche, and eventually brought its victims to the face of death is what makes the whole experience macabre. They beautifully capture the gruesome reality of Death. It also goes to show how meaningless the divides that man builds are as in death, every man has the same end. Though the Black Death caused mass deaths and deep-seated grief in the living, people still lived by the hope of a better tomorrow and sought refuge and solace in their faith. While the Black Death occurred centuries ago, it is of great significance today when we live our lives through a pandemic. The widespread and sudden outbreak left deep-rooted impressions on the hearts and minds of the medieval people. These works awaken us to the realization that regardless of the differences in time and space, the soul of man is essentially the same.

\section{References}

Aberth, John. (2005). The Black Death: The Great Mortality of 1348-1350, A Brief History with Documents. Boston and New York: Bedford/St. Martin's.

Anonymous. (Fifteenth Century). A Fifteenth Century Chronicle of Constance [Painting]. https://in.pinterest.com/pin/290834088420877209/

Ashcroft, Bill, Griffins, Gareth, \& Tiffin, Helen (Eds.). (2004). Key Concepts in Postcolonial Studies. London: Routledge.

Bakhtin, Mikhail. (1968). Rabelais and His World (Hélène Iswolsky, Trans.). Indiana University Press. (Original work published 1965).

Boccaccio, Giovanni. (2018). The Decameron (J.M. Rigg, Trans.). Digireads.com. (Original work published 1353).

Boeckl, Christine M. (1997). The Pisan Triumph of Death and the Papal Constitution Benedictus Deus. Artibus et Historiae, 18(36), 55-61. https://doi.org/10.2307/1483598

Cantor, Norman F. (2001). In the Wake of the Plague: The Black Death and the World it Made. New York: Simon \& Schuester.

Carrade, Shirley M. (2016). The Black Death in the Medieval World: How Art Reflected the Human Experience Through a Macabre Lens. (Senior Theses and Capstone Projects). Retrieved from https://scholar.dominican.edu/senior-theses/41

DesOrmeaux, Anna Louise. (2007). The Black Death and its effect on fourteenth-and fifteenth-century art. (Master's Theses). Retrieved from https://digitalcommons.lsu.edu/gradschool_theses/ 1641

Dirlik, Arif. (2005). The Postcolonial Aura: Third World Criticism in the Age of Global Capitalism. In Gaurav Desai and Supriya Nair (Eds.), Postcolonialisms: An Anthology of Cultural Theory and Criticism (pp. 561-588). Rutgers University Press.

Gertsman, Elina. (2003). The Dance of Death in Reval (Tallinn): The Preacher and His Audience. Gesta, 42(2), 143-159. https://doi.org/10.2307/25067083 
Langer, William L. (2011). A Psychological Perspective of the Black Death. Our Lady of Mercy Academy.

https://www.olma.org/ourpages/auto/2018/12/5/47726943/Psychological\%20Perspecti ve\%20on\%20Black\%20Death-Langer\%20_1_.pdf

Mercer, Kobena. (2013). Postcolonial Grotesque: Jane Alexander's Poetic Monsters. Nka Journal of Contemporary Letters, 2013(33), 80-91. https://doi.org/10.1215/107571632352830

Notke, Bernt. (c. 1463-1466). Dance of Death [Painting]. https://mydailyartdisplay.wordpress.com/2011/07/19/dance-of-death-by-bernt-notke/

Thompson, James Westfall. (1921). The Aftermath of the Black Death and the Aftermath of the Great War. American Journal of Sociology, 26(5), 565-572. Retrieved from http://www.jstor.org/stable/2764425

Traini, Francesco. (c. 1350). Triumph of Death [Painting]. https://www.wga.hu/html_m/t/traini/triumph.html

Tuchman, Barbara. (1978). A Distant Mirror: The Calamitous 14th Century. New York: Alford A. Knopf.

\section{$\underline{\text { Bio-note }}$}

Jane Mary Joseph is a Research Scholar pursuing Ph.D in the Department of English, Mizoram University.

Email: janemjoseph@gmail.com.

K.C. Lalthlamuani is a Professor and currently the Head, Department of English, Mizoram University.

Email: kayz1511@gmail.com. 